\title{
Exploring The Critical Factors Influencing the Using eLearning During the Covid-19 Pandemic: Case Study in Aljafara University Libya
}

\author{
Basma Emhamed Dihoum ${ }^{1}$, Siham Saleh Al-Qiblawi ${ }^{2}$ \\ ${ }^{1}$ Aljafara University, College of Science and Natural Resources, Computer Department \\ ${ }^{2}$ Aljafara University, College of Science and Natural Resources, Mathematics Department
}

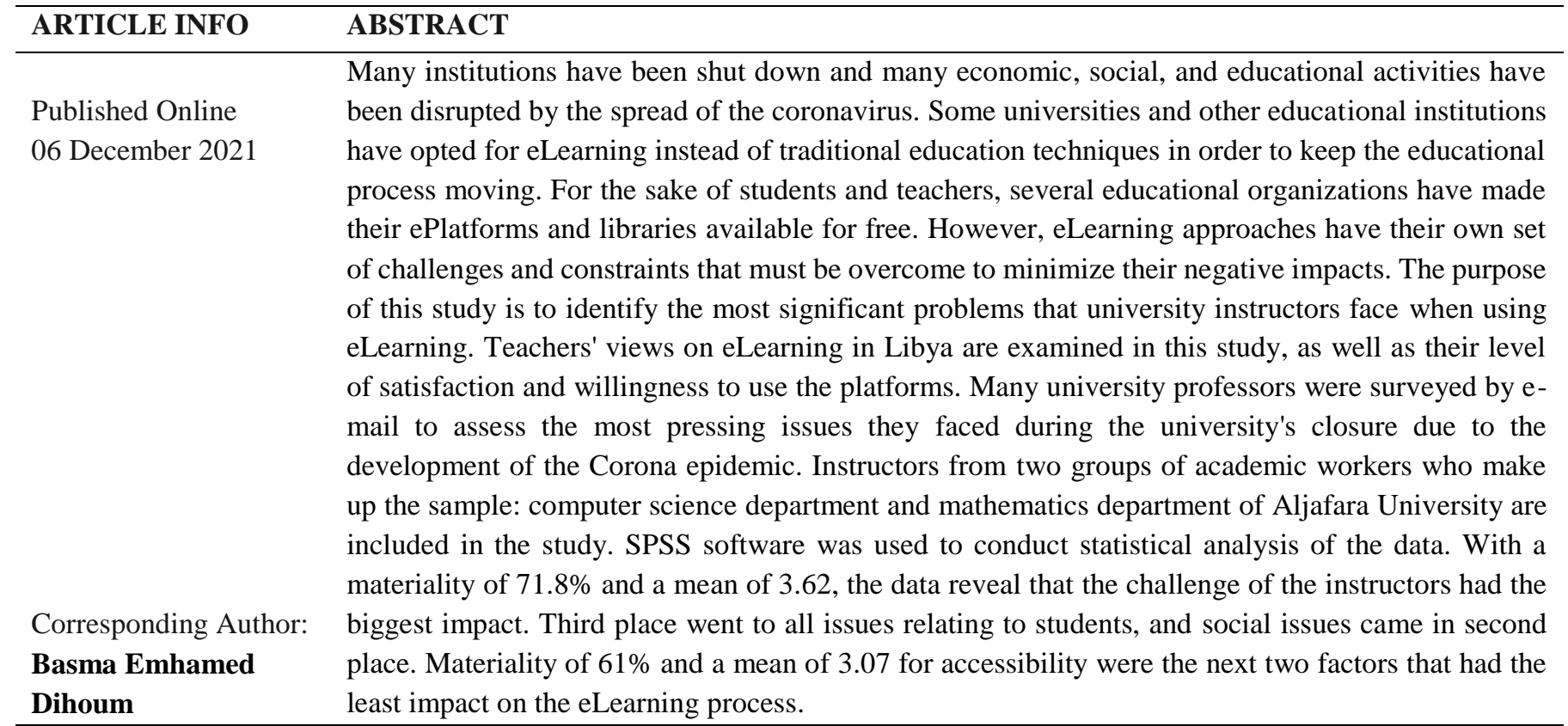

KEYWORDS: eLearning, Libya, Aljafara University, COVID-19 pandemic

\section{INTRODUCTION}

As a result of the Coronavirus disease 2019 (Covid-19), the school system around the world has been substantially restructured. Covid-19 is an infectious disease caused by a coronavirus that was initially detected in Wuhan, a city in China, and soon spread throughout the country. In order to prevent the spread of this extremely contagious disease, health agencies have put together a massive effort to implement safety measures like as quarantine restrictions and social destining rules (Khadija Alhumaid, 2020). More than 78,000 Covid-19-infected patients were diagnosed in Libya in November 2020, and 1,102 of them have died, while the number of persons who have been declared cured stands at 49,592 (Jadoo et al., 2021; Abdullah et al., 2019). To limit the spread of this virus, many countries including Libya implemented epidemic policies, which obliged educational institutions to suspend their activities. During the quarantine, several educational institutions looked for alternate alternatives, and the majority of them turned to internet resources to continue their studies.

Teaching professionals and students are virtually connected via the internet and appropriate electronic devices (e.g., smartphones, tablet computers, etc.) in eLearning or virtual education (Abidah et al., 2020; Sathishkumar et al., 2020). Students, academic staff, and electronic infrastructure all need to be in place for technology-based eLearning to be a successful style of education. As a result of the coronavirus's proliferation, teachers or instructors are the most important members of any educational institution. Teachers also believe that the traditional technique of teaching is the best way to go because they are unfamiliar with eLearning and its advantages (Al-Alak and Alnawas, 2011). The purpose of this study is to find out how Aljafara 


\section{Aljafara University Libya"}

University's academic staff feel about eLearning acceptability, adoption, and integration during the Covid19. In this study, we looked at how instructors see eLearning's usefulness and the potential pitfalls that can arise when using it.

\section{LITERATURE REVIEW}

Academics at the International Islamic University in Malaysia are being studied in (Agboola, 2006) to see if they are ready for the implementation of eLearning. All 324 participants were surveyed, and 98 percent of them responded. According to the study's conclusions, academics were making significant progress. Due to a lack of personal skill and infrastructure, however, they still have some time to solve their current issues.

An investigation of teachers' views on online learning as an alternative to traditional teaching during the Covid19 outbreak was undertaken in (Khadija Alhumaid, 2020). Thirty Pakistani university professors from Rawalpindi participated in the study, which was based on the Technology Acceptance Model (TAM). The findings showed that students had a favorable view of eLearning acceptability and influence during quarantine. In spite of this, the Education Ministry of Pakistan has numerous obstacles in its efforts to introduce eLearning, including a lack of funding and an array of students' differing views on the subject. The researchers concluded that more research into instructors' perceptions of the significance of eLearning is needed.

During the shutdown, 23 academic ophthalmologists from six Jordanian medical schools participated in a cross-sectional survey to assess their experiences with eLearning and the benefits and drawbacks that come with it (Alqudah et al., 2020). In this study, the majority of respondents (95.5 percent) were in favor of eLearning's time and location flexibility; nonetheless, the majority (77.3 percent) believed that a lack of necessary skills was a key deterrent to eLearning. Furthermore, a large majority of those polled (86.4\%) expressed dissatisfaction with eLearning as the sole form of instruction. And last, eLearning is positively received by participants, who believe it will play an essential role in the future.

Benghazi University's department of nursing performed a descriptive survey to see how ready they are for e-learning. The results may be found in (Contreras and Hilles, 2015). eLearning can be used more effectively if this research is used. According to the findings of this study, eLearning has a good impact on both the teaching staff and students. However, there are still some areas in the faculty that need to be addressed. For the purpose of assessing the impact of eLearning on Saudi Arabia's pharmacy education, two crosssectional Likert-scale-based questionnaires were used (Alqurshi, 2020). More over 60 percent of teachers at 10 area colleges took part in the poll, which was sent out to 74 faculty members from those institutions. Seventy-one percent of educators agree that the use of electronic learning has a beneficial impact on students' abilities.

It is the purpose of this case study to examine the views and experiences of academic staff at the University of South Africa's Department of Information Science on e-learning. We collected data through a variety of means, including direct observation, in-depth interviews, and document analysis. The results of the study show that participants recognize the importance of eLearning, despite the fact that some have difficulty grasping the concept. A better approach for eLearning should be developed in light of the findings of this study in order to alleviate the educational community's apprehension about its use (Ncube et al., 2014).

According to Elberkawi, Ateeyah, et al., (2020) the goal of this research project is to examine the viewpoints of students and instructors on the adoption and usage of eLearning technologies as a supplement to traditional classroom instruction. The University of Aljafara's computer and mathematics faculty members and students were received a copy of one of two surveys. A recent study found that educators generally agreed that implementing eLearning would help students gain more proficiency with computers. Furthermore, the lack of financial resources was seen as a major roadblock in the implementation of an eLearning system. It was suggested in the study that educational institutions should provide internet connectivity to students and faculty members with suitable computing equipment at a lower fee in order to create awareness about using the eLearning system. The university's IT infrastructure must also be upgraded to enable eLearning in order to ensure that all staff receive proper training (Altawaty et al., 2020).

\section{RESEARCH METHODOLOGY}

There are two groups of academic workers who make up the sample: science and natural resources, computer science, and mathematics. The study focuses on these three groups. During the pandemic coronavirus interval in Aljafara University, scientific limits were used to investigate the challenges faced by academic personnel employing eLearning instruction. It is important to keep in mind that the research sample is made up of teachers from a variety of departments, and that their time constraints and the diverse hours they spend in respective departments are taken into consideration (Elberkawi et al., 2020). As a result, we decided to use Google Forms because they would be ideal for attracting the most participants in the least amount of time. Two sections are included in the questionnaire: Demographic information is the focus of Section I. Students, instructors, and accessibility issues are all taken into account on the Second II, which is divided into four subcategories. The total number of questionnaires that were distributed was 38 . Only two copies of the 


\section{"Exploring The Critical Factors Influencing the Using eLearning During the Covid-19 Pandemic: Case Study in Aljafara University Libya"}

document were found to be in incorrect, resulting in 36 legal copies.

\section{THE FINDINGS}

The SPSS (SPSS version 23) statistical package is used to analyze statistical data. All items were rated on a five-point Likert scale ranging from strongly disagree to strongly agree, with a score of one to five. There is no appropriate expenditure in infrastructure to support electronic performance, with a mean of 3.70 , followed by "It is very difficult to follow the classes owing to acute power shortage" with a materiality of $65.7 \%$ and a mean 3.16 in Table 1 . The investigation (4) comes in last place, with a materiality score of only 42.5 percent and a mean score of 2.20 points.

Table 1: Descriptive Statistics of Accessibility problems

\begin{tabular}{|l|l|l|l|l|l|}
\hline S.N. & Items & Mean & STDev & Materiality & Rank \\
\hline 1 & I encounter issues when navigating through ELearning applications & 2.42 & 1.027 & 46.2 & 5 \\
\hline 2 & $\begin{array}{l}\text { There is no adequate expenditure in infrastructure to support } \\
\text { electronic performance. }\end{array}$ & 3.67 & 1.277 & 74 & 1 \\
\hline 3 & I am not able to easily access the Internet as needed. & 2.75 & 1.324 & 56.2 & 4 \\
\hline & $\begin{array}{l}\text { I do not have the available IT infrastructure for doing online work. Ex } \\
\text { (good phone, computer, etc.) }\end{array}$ & 2.20 & 1.199 & 42.5 & 6 \\
\hline 5 & It is very difficult to follow the classes due to acute power shortage & 3.16 & 1.116 & 65.7 & 2 \\
\hline 6 & It is very difficult to follow the classes due to poor internet connection & 2.78 & 1.244 & 57 & 3 \\
\hline
\end{tabular}

As shown in Table 2, the highest materiality of 79.1 percent and a mean of 3.90 is "I feel that face-to-face contact with my students is necessary to learn," which is followed by the inquiry (2), which declares that "The inability to sense students' interaction as in the classroom" with the materiality of 78.6 percent. While question (1) has a materiality of 59.8 percent and a mean of 3.03 , it is listed last in the list of questions.

Table 2: Descriptive Statistics of Social problems

\begin{tabular}{|l|l|l|l|l|l|}
\hline S.N & Items & Mean & STDev & Materiality & Rank \\
\hline 1 & The student is unable to ask questions or get answers & 3.03 & 1.202 & 59.8 & 5 \\
\hline 2 & The inability to sense students' interaction as in the classroom & 3.87 & 1.147 & 78.6 & 2 \\
\hline 3 & I cannot teach as well as I am in the classroom with students & 3.07 & 1.244 & 61.4 & 4 \\
\hline 4 & $\begin{array}{l}\text { I do not feel effective communication with my classmates and } \\
\text { students electronically }\end{array}$ & 3.18 & 1.131 & 63.6 & 3 \\
\hline 5 & $\begin{array}{l}\text { I feel that face-to-face contact with my students is necessary to } \\
\text { learn }\end{array}$ & 0.904 & 79.1 & 1 \\
\hline
\end{tabular}

Table 3 shows that the most materiality of 83.2 percent and a mean of 3.75 is found in inquiry (3), which states that "Students feeling anxious when dealing with tests through the eLearning system," followed by inquiry (2), which states that "Students do not view educational websites frequently, resulting in their delay in obtaining tasks and advertising." A mean score of 3.21 is found for inquiry (4), which indicates that "Students' inability to communicate with their professors" is the least significant finding.

Table 3: Descriptive Statistics of Student problems

\begin{tabular}{|l|l|l|l|l|l|}
\hline S.N. & Items & Mean & STDev & Materiality Rank \\
\hline 1 & The students not willing to participate in eLearning activities. & 3.25 & 1.195 & 65.01 & 4 \\
\hline 2 & $\begin{array}{l}\text { Students do not view educational websites frequently, resulting in their } 3.49 \\
\text { delay in obtaining tasks and advertising. }\end{array}$ & 1.112 & 69.8 & 2 \\
\hline 3 & $\begin{array}{l}\text { Students feeling anxious when dealing with tests through the eLearning } \\
\text { System. }\end{array}$ & 3.75 & 1.136 & 83.2 & 1 \\
\hline 4 & $\begin{array}{l}\text { The inability of students to communicate with their teachers } \\
\text { The student's performance in eLearning is weaker than in the face-to-face } \\
\text { learning method. }\end{array}$ & 3.21 & 1.129 & 64.4 & 5 \\
\hline 5 & 642 & 67.2 & 3 \\
\hline
\end{tabular}

In Table 4, when it comes to some subjects, traditional education is more meaningful than eLearning, with an 83.4 percent and 4.09 mean, followed by the inquiry (1), which claims that "In the eLearning process, the Teaching Staff 


\section{"Exploring The Critical Factors Influencing the Using eLearning During the Covid-19 Pandemic: Case Study in Aljafara University Libya"}

carries the most load," with a 76.3 percent and 3.82 mean. came in last position Question \#2, with a materiality of $62 \%$ and a mean of 3.08 ,

Table 4: Descriptive Statistics of Instructors problems

\begin{tabular}{|l|l|l|l|l|l|}
\hline S.N. & Item & Mean & STDev & Materiality & Rank \\
\hline 1 & In the eLearning process, the teaching staff carries the most load. & 3.82 & 1.035 & 76.3 & 2 \\
\hline 2 & $\begin{array}{l}\text { The difficulty of evaluating the student through eLearning programs in terms } \\
\text { of not guaranteeing the student's identity. }\end{array}$ & 3.08 & 1.229 & 62.1 & 5 \\
\hline 3 & I believe that sharing information through online discussions takes time. & 3.52 & 1.144 & 70.8 & 3 \\
\hline 4 & In some subjects, traditional education is more meaningful than eLearning. & 4.09 & 0.917 & 81.2 & 1 \\
\hline 5 & Uploading coursework is not an easy task. & 3.12 & 1.331 & 62.4 & 4 \\
\hline
\end{tabular}

From the perspective of instructors, this is a comparison between the mean scores of students on each of the four difficulty levels studied. With a materiality of $71.8 \%$ and a mean of 3.62, the results in Table 5 suggest that the teachers' challenge was the most important and had the biggest impact. E-impact learning's on social issues, which ranked second in terms of materiality with a mean of 3.48 percent, had a minor difference in materiality. Materiality of $61 \%$ and a mean of 3.07 put accessibility in third place in the eLearning process, followed by all student-related difficulties, with $67 \%$ and a mean of 3.34 .

Table 5: eLearning challenges

\begin{tabular}{|l|l|l|l|l|}
\hline Challenges & Mean & STDev & Materiality & Rank \\
\hline Instructors Issues & 3.62 & 1.166 & 71.8 & 1 \\
\hline Student Issues & 3.34 & 1.125 & 67.1 & 3 \\
\hline Social Issues & 3.48 & 1.133 & 68.2 & 2 \\
\hline Accessibility Issues & 3.07 & 1.176 & 60.7 & 4 \\
\hline
\end{tabular}

\section{CONCLUSION AND RECOMMENDATIONS}

Many impediments and challenges continue to be faced by eLearning, despite the fact that numerous initiatives have been taken to reduce the increase in these barriers. The Corona pandemic evolved in the backdrop of all of these reasons, allowing the entire world to partake in electronic education with all of its ramifications. During the coronavirus epidemic, this study aims to highlight the main concerns and challenges that teachers face when using eLearning in a private institution. There are 17 faculty members from two department of Aljafara University, Libya, included in the study sample. Analysis of the SPSS data from electronic questionnaires issued to the sample members yielded some recommendations for improvement. Following social issues, which have the second-highest impact on eLearning, are difficulties relating to instructors' challenges. Students' concerns and accessibility occupied the final two spots on the list. Each difficulty level has been assigned a set of key recommendations. The order in which these suggestions are made will be determined by the final rankings.

For the instructor's concerns, here are a few suggestions: In order to improve eLearning, techniques and tools for teaching courses of a certain sort must be developed, which traditional education now outranks eLearning in. The faculty member should be assisted in their use of the eLearning approach. This aims to ensure that the eLearning process runs smoothly, and one of these techniques is to supply faculty members with free paid scientific apps. This includes modern facilities, unlimited internet access, and free subscriptions to eLearning platforms or tools for teaching professionals at educational institutions.

Second, suggestions for dealing with challenges relating to society: Providing eLearning courses to senior faculty members as a way to help them keep up with modern education methods, as some of them have been accustomed to traditional education for a long length of time. They did not feel totally at ease with the technology advancements in education and frequently wished for a return to conventional eLearning methods.

Accessibility recommendations: We must ensure that students and teachers have easy and convenient access to the Internet, information technology, and a variety of distant education platforms. Students and professors will be able to communicate more effectively, providing a better learning environment in which information and scientific materials are available on time to support the distance education process.

Recommendations for students who are experiencing difficulties: It's critical to inform students about the value of regularly visiting and using sites and applications that connect them to their teachers, such as Classroom, Mobile apps and social media might be used to spread this message, as well as advertising in educational institutions. 


\section{Aljafara University Libya"}

The purpose of these visits is to correct and follow up on any issues that may affect their courses.

\section{REFERENCES}

1. Abdullah, F.M., Maatuk, A.M., Mohammed, A.A. and Elberkawi, E.K., 2019. Application of electronic management system in governmental institutions: An empirical study on the Libyan civil registration. In PervasiveHealth: Pervasive Computing Technologies for Healthcare. ICST.

2. Abidah, A., Hidaayatullaah, H.N., Simamora, R.M., Fehabutar, D. and Mutakinati, L., 2020. The impact of covid-19 to indonesian education and its relation to the philosophy of "merdeka belajar." sciejournal.com, 1(1), pp.38-49.

3. Agboola, A., 2006. Assessing the awareness and perceptions of academic staff in using e-learning tools for instructional delivery in a post-secondary institution: A case study. The Innovation Journal: The Public Sector Innovation Journal, 11(3), pp.112.

4. Al-Alak, B.A. and Alnawas, I.A.M., 2011. Measuring the acceptance and adoption of elearning by academic staff. Knowledge Management and E-Learning, 3(2), pp.201-221.

5. Alqudah, N.M., Jammal, H.M., Saleh, O., Khader, Y., Obeidat, N. and Alqudah, J., 2020. Perception and experience of academic Jordanian ophthalmologists with E-Learning for undergraduate course during the COVID-19 pandemic. Annals of Medicine and Surgery, 59, pp.44-47.

6. Alqurshi, A., 2020. Investigating the impact of COVID-19 lockdown on pharmaceutical education in Saudi Arabia - A call for a remote teaching contingency strategy. Saudi Pharmaceutical Journal, 28(9), pp.1075-1083.

7. Altawaty, J.A., Benismail, A. and Maatuk, A.M., 2020. Experts opinion on the IT skills training needs among healthcare workers. In PervasiveHealth: Pervasive Computing Technologies for Healthcare. ICST.

8. Contreras, J.O. and Hilles, S.M.S., 2015. Assessment in E-Learning Environment Readiness of Teaching Staff, Administrators, and Students of Faculty of Nursing-Benghazi University. International Journal of the Computer, the Internet and Management, 23(1), pp.53-58.

9. Elberkawi, E.K., Ateeyah, M.A., Elakeili, S.M. and Maatuk, A.M., 2020. Issues and challenges of implementing E-learning in a public university: Students and instructors perspective. In PervasiveHealth: Pervasive Computing Technologies for Healthcare. ICST.
10. Elberkawi, E.K., Dakhil, M.I., Almukhtari, A.A. and Maatuk, A.M., 2020. Assessing quality standards in electronic gates of educational institutions: A field study. In PervasiveHealth: Pervasive Computing Technologies for Healthcare. ICST.

11. Jadoo, S.A.A., Danfour, O.M., Zerzah, M., Abujazia, M.A., Torun, P., Al-samarrai, M.A.M. and Yaseen, S.M., 2021. Knowledge, attitude, and practice towards COVID-19 among Libyan peoplea web-based cross-sectional study. Journal of Ideas in Health, 4(Special1), pp.348-356.

12. Khadija Alhumaid, S., 2020. COVID-19 \&Elearning: Perceptions \&Attitudes Of Teachers Towards E-Learning Acceptancein The Developing Countries. Multicultural Education, 6(2), pp.10-0.

13. Ncube, S., Dube, L. and Ngulube, P., 2014. Elearning readiness among academic staff in the Department of Information Science at the University of South Africa. Mediterranean Journal of Social Sciences, 5(16), pp.357-366.

14. Sathishkumar, V., Radha, R., Saravanakumar, A. and K. Mahalakshmi, 2020. E-Learning during Lockdown of Covid-19 Pandemic: A Global Perspective. International Journal of Control and Automation, 13(June), pp.1088-1099. 